\title{
'BLOOD AS THE SEAT OF LIFE’: THE BLOOD PARADOX AMONG AFRO-CHRISTIANS
}

\author{
Francis MACHINGURA*, GOdFrey MUSEKA** \\ University of Zimbabwe
}

\begin{abstract}
The study is a response to the call for papers on African issues and it focuses on the theme of blood. The chapter seeks to answer the following questions: Why is blood, the sanctity of life, associated with defilement? How can the good and purity of life which blood symbolizes come out of impurities? How is the practice of blood manipulation represented in biblical texts? How can bodily refuse in this case blood be conceived as a symbol of purity, power and danger? How do readers of biblical texts understand the textual representations and interpretations of blood? Does each mode of blood manipulation rituals function as communicative symbols? Our response to these questions is threefold. First, we consider the sanctity of blood in relation to its purity and power. This is followed by an examination of danger beliefs associated with blood and lastly by an analysis of the sacred/taboo or purity/danger dichotomy within the context of the Old Testament and the New Testament as well as of the Shona AfroChristians.
\end{abstract}

KEY WORDS: Blood, Purity, Impurity, Israel, Shona, Zimbabwe

\section{Introduction}

The mystery and sanctity of human life and indeed of the life of animals are inextricably bound to blood. In the Afro-Christian religious tradition, blood is the centrifugal force around which most rituals gravitate. The sanctity of blood however is held in sharp contrast to beliefs about the danger associated with it. This makes blood one of the most ambiguous aspects of rituals among Shona Afro-Christians in Zimbabwe. The ambiguity is aptly captured in Nabofa's (1985:391) submission that the sanctity of blood among many African tribes stands in sharp contrast to the practice of ritual sacrifice that involves the shedding of blood. Among various religious groups and in

* FRANSIS MACHINGURA (PhD 2012, University of Bamberg, Germany) is lecturer in inter-contextual theology at the Department of Education within the University of Zimbabwe. Email: fmachingura@yahoo.com.

** GODFREY MUSEKA (MA 2001, University of Zimbabwe) is lecturer in religious studies at the Department of Religious Studies within the University of Zimbabwe. Email: godiemuseka@gmail.com. 
particular Shona Afro-Christians, blood is conceived as an embodiment of beneficial as well as malevolent mysterious powers which can cleanse and defile.

By Shona Afro-Christians, we mean Shona people who simultaneously practice African indigenous religions and Christianity as well as constitute about 50 percent of the Zimbabwean population (http://www.indexmundi.com/-zimbabwe/religions.html). The understanding of blood is associated with various symbolic meanings in both the Old and the New Testament. The biblical understanding of blood is similar to the understanding found amongst Shona traditionalists as shall be shown in this chapter. The AfroChristians are guided in their day-to-day religious practice not only by the Bible but also by indigenous beliefs. Given the centrality of blood to the lives and religio-cultural cosmology of the Shona Afro-Christians, this study interrogates the basis of blood ambiguity in terms of the attitudes, perceptions, beliefs, and symbolisms that underpin this paradox.

\section{The Sanctity of Blood in the Old Testament}

Blood is a central theme in the Bible especially in the Old Testament. The Hebrew word for blood dam occurs more than 300 times in the Old Testament (Kent: 2011). The statistical evidence shows that of the 362 passages in which the word dam occurs in the Old Testament, 203 refer to death by violence. Only six passages connect life with death. Scholars are therefore compelled to link dam with death since there is little evidence adduced in support of the life theory (Marshall, Millard, Packer, and Wiseman 1997:1). According to Kent (2011:1), the Old Testament is a bloody book which is full of stories of war, covenant blood rituals, and violence (and in which God slew animals to clothe Adam and Eve in Genesis 3:21). However, the biblical stories and laws despite their visceral imagery all convey respect for life. It is important to note that blood had symbolic life significance whereas in some societies blood can symbolically mean death. There is unanimity amongst scholars that blood holds a place of high esteem and wonder in many societies as it is associated with life. The understanding in the Old Testament is that life is in the blood and the flow of blood signifies that life flows with it and belongs to YHWH and not to individuals (Preuss 1996:12). Blood and life therefore become significantly sacred. Blood is associated with a variety of taboos in many cultures where humans do not have the power of disposal over blood even though they can eat animals.

The story of Abel and Cain comes to mind (Genesis 4:10). After Abel's 'blood cried out' to God, God called Cain to accountability for killing his brother. The Old Testament especially the pages of the Pentateuch is filled with specific prohibitions and punishment for killing-whether carried out accidentally or intentionally. The Jewish laws prohibited eating or drinking 
blood, and this stood in sharp contrast to pagan rituals (Genesis 9:1; Leviticus $7: 27 ; 7: 17)$. In the Old Testament tradition, 'to eat someone's flesh' is a symbol of hostile action (Psalm 27:2; Zechariah 11:9). According to Brown, Bernard, Malina, and Rohrbaugh, it is not surprising that the drinking of blood was regarded also as a horrendous thing forbidden by God's law (Genesis 9:4; Leviticus 3:17; Deuteronomy 12:23; Acts 15:20); for the blood of animals was tabu and it was forbidden to be eaten as food (Genesis 9:4; Deuteronomy 12:16). Some scholars hold that in the sacrificial system of the Old Testament, blood represents life liberated from the limitations of the body and set free for other purposes. In this view, the ceremonial manipulation of blood also represents the solemn presentation to God of life-life surrendered, dedicated, and transformed (Marshall, Millard, Packer, and Wiseman 1997). Death occupies a subordinate place, even no place at all. The taboos associated with blood are interpreted in various ways but blood in whatever form could not be eaten or consumed along with meat.

Blood is regarded as 'life' or 'the seat of the soul' (Genesis 9:4). Deuteronomy 12:23 states this clearly: 'Only be sure that you do not eat the blood; for the blood is the life, and you shall not eat life with meat.' Similarly, Leviticus 17:11, 14, and 19:26 state that 'you shall not eat anything with its blood'. From a gender perspective, women are the most hurt as those with an issue of blood or menstruation are considered in the Jewish context as religiously and ceremonially unclean until the time required for purification lapses (Efird 1982:12). Guilders (2004:10) adds that,

The rabbinic sages and the author of Hebrews refer to a significant element in the cultic practice represented in the Pentateuch and elsewhere in the Hebrew Bible: manipulation specialized handling and use of the blood of sacrificial animals to achieve a variety of effects. We find, for example, references to the tossing of blood onto an altar or assembly of people, to the pouring out of blood at the base of the altar or onto the ground, to daubing onto the altar's horns or parts of the human body, and to sprinkling onto or in front of appurtenances of sacred space. Biblical texts and their subsequent reader-interpreters attribute a variety of effects to these ritual blood manipulations: purification from impurity or sin, consecration, transformation of identity or status, and protection from a destructive force.

Blood manipulation through performance of rituals played a critical role in creating and enacting the expected social-cultural, economic and religious relationship between the people and YHWH. In the Old Testament, rituals created a sacred space where the divine presence manifested, and blood rituals united the people and the gods. Such rituals are regarded by many scholars and interpreters as 'pre-eminently a form of communication' about the existing personal or social situations, that is, existing status or identity of the participants and the context in which they find themselves. The feasts 
and festivals involved blood, for example, the Passover feast which involved the blood of lambs smeared around the doors to remind the Israelites of their deliverance from Egypt. The Passover is believed to have combined elements of sacrifice as an apotropaic and sacrifice as a communion meal in which the blood sprinkling purified the covenant and the eating of the meal marked its consummation (Exodus 12; Exodus 24:1-8; Deuteronomy 27:1ff; Joshua 5:5-12; 8:30ff; Psalm 50:5; cf. Marshal, Millard, and Wiseman 1997:23). According to McCarthy and Kertzer, all symbols including ritual symbols in the Old Testament characteristically possess properties of 'condensation of meaning, multivocality, and ambiguity' where,

Condensation refers to the way in which individual symbols represent and unify a rich diversity of meanings, for example, the symbol somehow embodies and brings together diverse ideas. It therefore refers to the interaction of these different meanings. Multivocality refers to the variety of different meanings attached to the same symbol by different people in different ways. Ambiguity would then come in to show that, the symbol has no single precise meaning.

The understanding of blood in multivocal ways in different communities plays a significant role in what counts as ritual. This brings us to the question of covenant related agreements such as Mosaic and Abrahamic covenants which according to biblical records were conditional. Youngblood (1998) notes that the Old Testament shows that God's covenant blessings would only be contingent upon the willingness of the Israelites to abide by YWHW's commandments (Exodus 19:8; 24:3, 7). The seriousness of the matter and agreement is shown when the blood of animals is spilt to confirm the covenant.

For Hagee (2001:40), three kinds of covenants are observable-a shoe covenant, a salt covenant, and a blood covenant. In this study, the focus is on blood covenant which seems to have been prevalent in different communities including the Israelite and Shona communities. Exodus 24:3-8 reports that,

${ }^{3}$ Moses came and told the people all the words of the Lord and all the ordinances; and all the people answered with one voice, and said, 'All the words which the Lord has spoken we will do'. ${ }^{4}$ And Moses wrote all the words of the Lord. And he rose early in the morning, and built an altar at the foot of the mountain, and twelve pillars, according to the twelve tribes of Israel. ${ }^{5}$ And he sent young men of the people of Israel, who offered burnt offerings and sacrificed peace offerings of oxen to the Lord. ${ }^{6}$ And Moses took half of the blood and put it in basins, and half of the blood he threw against the altar. ${ }^{7}$ Then he took the book of the covenant, and read it in the hearing of the people; and they said, 'All that the Lord has spoken we will do, and we will be obedient'. ${ }^{8}$ And Moses took the blood 
and threw it upon the people, and said, 'Behold the blood of the covenant which the Lord has made with you in accordance with these words'.

Exodus 24:6 which says, 'and Moses took half of the blood and put it in basins, and half of the blood he threw against the altar', relates so well to the traditional ways of solemnizing covenants. The contracting parties would convey their agreement to the terms of the covenant by killing an animal or animals, splitting the carcass(es) in half, down the backbone, and placing the divided parts opposite each other on the ground to form a pathway between the pieces (Hagee 2001:25). The two contracting parties would then join hands, recite the contents of the covenant, and walk between the divided halves of the slain animals. The strange behavior by Moses when he sprinkled half of the blood of the animals against the sacrificial altar (24:6) and half on the people themselves (24:8) mirrors the covenantal practices of the time. It probably constituted the alternate way of symbolizing the willingness of the participants to abide by the terms of the covenant in which the altar represents the Lord's side of the agreement as well as the people's submission to the ritual (Youngblood 1998:49; Hagee 2001:25). The manipulative use of blood by Moses assumes significance as a visible way or means of drawing together YWHW and His people as contracting parties to the terms of the covenant. The blood covenant entered into by the contracting parties meant that they were now bound until death such that if either party broke the terms of the covenant, the offending partner's blood would be spilled like the blood of the animals that was killed (Hagee 2001:25). The sacrificial victim had to be taken from the clean animals and birds (Genesis $8: 20)$. Thus, the blood covenant united the two parties.

Sacrificial victims are associated with different symbolic meanings in different religious traditions. Hagee (2001:26) is concerned with the situatedness of the reader who reads and interprets as part of an interpretive community' constituted by a specific body of rules and principles for identifying and making sense of a text. The reader of the biblical text in this case takes into account the academic scholars (who evoke modern historicalcritical interpretive methods of understanding the Bible) and the generality of the people who are outside the academic circle but still find sense or meaning in what the biblical text says on blood. Iser sees readers as inevitably experiencing 'gaps' in the text before them as they read and apply them to their day to day lives. The usefulness and meaning of the text comes into being when it is read. It is the readers in any given society who fill in the 'gaps' in a bid to come up with a coherent understanding of the meaning of the biblical texts on blood. Thus, Afro-Christians have their own reading lenses that help them look at their environment when engaging with the Bible, in this case, the biblical texts on blood. 
Many scholars have quoted Leviticus 17:11 as one of the texts that provide the key understanding of all acts of the cultic blood manipulation in the Old Testament. Leviticus 17:11 which reads, 'for the life of the flesh is in the blood; and I have given it to you for making atonement for your lives on the altar; for, as life, it is blood that makes atonement', has also been applied to other animal sacrifices. Other Old Testament texts such as Genesis 9:4; 37:21ff; Leviticus 3:17; 4:5-34; 16:14-19; 17:14, and Deuteronomy 12:23 have also been identified with the blood animation, the 'life' of the body. The human contact with a sacrificial animal and its parts which would have been divided creates social relations. In the Jewish context, blood served the purpose of atonement of sin as commanded by YHWH (Leviticus $4: 5-34 ; 16: 14-19$, and 17:11). Animals were then sacrificed to ward off evil or as atonement of sin (Exodus 29:20).

For Kent (2011:12), all the sacrifices or blood rituals also reminded the people that there was a price to pay for sin and one could not lightly come into the presence of God. There is a probability that costs will be involved from the possibility that some would not be cleansed from sin after blood rituals have been carried out. Blood in this case is the only price that God would accept for the forgiveness of sins as shown in the New Testament. According to Marshall, Millard, Packe, and Wiseman (1997:17), it is understandable that in some places in the Old Testament, atonement is said to have been secured by death, e.g., Numbers 35:33 which says 'for blood pollutes the land, and no expiation can be made for the land for the blood that is shed in it except by the blood of him who shed it' (cf. Exodus 29:33, Leviticus 10:17). Therefore, atonement is secured by the death of a victim rather than by its life, a notion that is carried over into the New Testament.

\section{The Sanctity of Blood in the New Testament}

The place and significance of blood in the New Testament does not differ much from the Old Testament. However, in the New Testament, the Old Testament stipulations gain new meanings in the figure of Jesus. Life is still physically and spiritually associated with blood as the life of a Christian depends on the shed blood of Jesus Christ (1 John 1:7; Ephesians 1:7; Colossians 1:14 and Hebrew 9:22). The human figure of Jesus plays a central role in the atonement and salvation of humanity. Ephesians 1:7 states that, in him we have redemption through his blood, the forgiveness of our trespasses, according to the riches of his grace'. God made Christ to be the propitiation by his blood (Romans 3:25); everyone is justified by his blood (Romans 5:9); we are made near to God by the blood of Christ (Ephesians 3:13); and peace is portrayed as only found through the blood of his cross (Colossians 1:20). Most of the New Testament passages on blood present in the plainest possible fashion that death is meant, for example, the phrase "justified by

PERICHORESIS 14.1 (2016) 
his blood' (Romans 5:9) is parallel to 'reconciled... by the death of his Son' in verse 10, and the reference to coming 'by water and blood' (1 John 5:6).

Liberal theologians find it difficult to accept the doctrine of the blood of Christ as they call it the 'slaughterhouse religion' (Wiersbe 1993:19)—Christ as the Lamb is crucified for the sins of the world that He did not commit. This opens up the concept of the covenant that was instituted as a result of the redemptive agreement or transaction consummated between God and the human race on Mount Golgotha in the first century through the blood of Jesus Christ. It was the plan of God to save people without the involvement of humanity. It is important to realize that the Old Testament helps us much to understand the idea of sacrifices and offerings in the New Testament. It is not easy to understand the blood language in the New Testament because the night before Jesus' death he celebrated the Passover with his disciples. We would never have understood the meaning of the blood and the covenant unless one knew of the Old Testament Passover, God's covenant with his people and the blood sacrifices that were associated with the atonement of peoples' sins. The New Testament passages on the blood of the covenant indicate that the term is used in the same way as in the Old Testament where it is understood that sacrifices were efficacious by virtue of the death of the victim. Accordingly, the blood of Christ should be understood as the atoning death of the savior. The New Testament books are quoted with the language of blood and when one has no knowledge of the Old Testament, the imageries of blood in the New Testament would not add up.

The picture of the suffering death of Jesus would appear to be that of a violent and cruel God. However, the Old Testament vocabulary and imagery help a great deal when reading and interpreting the New Testament. Paul talks of the Church as the 'temple of the living God' (2 Corinthians 6:16) and of the 'Israel of God' in Galatians 6:16 which then point back to the centrality of the Old Testament in understanding the New Testament of blood. In 1 Peter 2:9, the Church which is made up of Christian believers is described with Old Testament concepts such as 'a chosen race, a royal priesthood, a holy nation, and God's own people.' Ladd (1993:25) remarks that,

A moment's reflection suggests that such references are not primarily concerned with the actual physical blood of Jesus, for as a matter of fact, Jesus shed very little of his material blood. The idea of shedding blood refers to the slaughter of the sacrificial lamb, whose throat was cut and whose blood gushed forth. Nothing like that happened to Jesus. The blood and water that came from Jesus' side did so after he had expired (John 19:34). In the New Testament, blood means life violently taken away, life offered in sacrifice. It is presentation of life. The blood was regarded by the Hebrew as essentially the seat of life hence the death 
of the victim was not only a death but a setting forth of life: the application of life: and the offering of the blood to God was an offering of life hence the virtue of sacrifice.

By virtue of death, the life of Jesus was surrendered to God as sacrifice. The blood of Christ signifies nothing less than the life of Christ though the biblical evidence does not seem to support that. Taylor rightly captures this by showing 'the victim is slain in order that its life, in the form of blood, may be released... so as to make it possible for life to be presented as an offering to the Deity.' Several New Testament passages unanimously mention the covenant that came into being through the blood that was shed by Jesus (Matthew 26:26-29; Mark 14:22-25; Luke 22:17-19; 1 Corinthians 10:16; 11:23-26). For example, Matthew 26:26-29 states that:

${ }^{26}$ Now as they were eating, Jesus took bread, and blessed, and broke it, and gave it to the disciples and said, 'Take, eat; this is my body'. ${ }^{27}$ And he took a cup, and when he had given thanks he gave it to them, saying, 'Drink of it, all of you: ${ }^{28}$ for this is my blood of the covenant, which is poured out for many for the forgiveness of sins. ${ }^{29}$ I tell you I shall not drink again of this fruit of the vine until that day when I drink it new with you in my Father's kingdom'.

According to Harrington (1991:22), Matthew's account of Jesus' last Passover (Matthew 26:17-35) follows Mark 14:12-31 very closely though the few changes introduced by Matthew into his Markan source reflect his editorial practices and special interest which were in line with the evangelist's experience of liturgy in his own community. Matthew introduced minor changes in the Eucharistic words of the institution (Matthew 26:26-29) as in 'eat... drink from it... all of you... for the forgiveness of sins'. The statement introduces the Passover theme of liberation, in this case liberation from sin. The infancy narrative in Matthew 1:21 ('she will bear a son, and you shall call his name Jesus, for he will save his people from sins') confirms the mission of Jesus to be that of 'saving his people from their sins'.

Senior (1989:20) states that some theologians, biblical scholars, and Christian believers find the salvific blood mission of Jesus in His healings as a fulfilment of Isaiah 53:4, 'He took our infirmities and bore our diseases'. The Matthean additions possibly reflect the development of the Passover ritual in relation to the salvific blood covenant in Jesus' Last Supper where it became the central ritual of the Christian community which could be geographically celebrated repeatedly wherever and at any time. It is interesting that the textual version in Mark does not talk about 'forgiveness of sins' after 'eating' and 'drinking' but links eating and drinking to the kingdom of God. Senior (1989:13) is right to argue that the changes in Matthew reflect the impact of the liturgical usage in Matthew's text especially the significant 
addition of the phrase 'for the forgiveness of sins' to the words about the cup (Matthew 26:28, Mark 14:24). In fact, Mark 14:22-25 reads:

${ }^{22}$ And as they were eating, he took bread, and blessed, and broke it, and gave it to them, and said, 'Take; this is my body'. ${ }^{23}$ And he took a cup, and when he had given thanks he gave it to them, and they all drank from it. ${ }^{24}$ And he said to them, 'This is my blood of the covenant, which is poured out for many. ${ }^{25}$ Truly, I say to you, I shall not drink again of the fruit of the vine until that day when I drink it new in the kingdom of God'.

What the two evangelists agree on is the covenantal status established between God and humanity because of the blood of Jesus based on the image in the Passover. The same concept is raised in the entire New Testament. According to some scholars, the Passover was one of the pilgrimage feasts (Exodus 23:14-17; 34:18-26) in Jesus' time which however became the vehicle for Jesus' climactic meal with his disciples-a meal that recalled the many meals that characterized Jesus' public ministry and the bond that existed between Jesus and his own disciples as well as the future Christian believers (Harrington 1991:57). Bokser (1987:22) argues that,

The story of Jesus' last Passover would have been especially meaningful to Matthew's community. The Jewish Christians in it would have been very sensitive to the themes and rituals of Passover by continuing to celebrate it. But Jewish Christians faced as all Jews did after the destruction of the Jerusalem temple in AD 70 a serious problem: how to celebrate Passover now that pilgrimage to Jerusalem and slaughter of lambs in the temple were no longer possible? The rabbis responded to this problem by transforming the domestic, sacrificial meal described in the Bible into a non-sacrificial Seder meal by tying Jesus' final meal more closely to the Jewish Passover (Mark 14:12-16; Matthew 14:17-20).

Christians find in Jesus' last Passover or supper a fresh and meaningful way to resolve the difficulties they faced in not celebrating Passover practically. For Senior (1989:20), the Lord's Supper in Matthew contains several layers of meaning: a) within the flow of Matthew's story, the Supper functions as a final passion that predicts Jesus' death as stated in his own words and the gestures set in the Passover meal; b) the taking of the cup is taken as a symbol of Jesus' death; c) the Matthean Jesus interprets the broken bread and the cup poured out as done in death 'for many'. It is clear in Matthew though (as well as in the other gospels and the Pauline letters) that the salvific emphasis harmonizes with the overall theology of the authors. Jesus' trial, death, and resurrection found expression in the great themes of the Passover and the salvation that would come with it (see Mark 14:12-16; Matthew 14:17-20). 
The Lord's Supper or Eucharist is seen as a paschal memorial or postresurrection event. In its theological meaning and reality, the post-Easter community was excited by the understanding that their Lord had resurrected and was present in Spirit. Thus, they continued in a new form the pre-Easter meals of the feast of Jesus' death with his disciples (Martinez 2003:15). Leon-Dufour views the Eucharistic theology of the accounts of the Lord's Supper in the Early Church as narrated in Mark, Luke, and Matthew as part of the cultic tradition which sought to present the event of Calvary and Jesus' living presence in the lives of the believers (Martinez 2003:12). For Machingura (2012:17), the Gospel of John contains the most radical version of the Eucharist where the drinking of blood which was anathema to Jubilees becomes a core principle of Johannine Christianity as recorded in John 6:52-58:

${ }^{52}$ Then Jews then disputed among themselves, saying, 'How can this man give us his flesh to eat?' ${ }^{53}$ So Jesus said to them, 'Truly, truly, I say to you, unless you eat the flesh of the Son of man and drink his blood, you have no life in you; ${ }^{54}$ he who eats my flesh and drinks my blood has eternal life, and I will raise him up at the last day. ${ }^{55}$ For my flesh is food indeed, and my blood is drink indeed. ${ }^{56} \mathrm{He}$ who eats my flesh and drinks my blood abides in me, and I in him. ${ }^{57}$ As the living Father sent me, and I live because of the Father, so he who eats me will live because of me. ${ }^{58}$ This is the bread which came down from heaven, not such as the fathers ate and died; he who eats this bread will live forever'.

It is interesting that the movement of the narrative in John shows Jesus making a contrast between bread for the stomach (human plane) and bread for the soul (spiritual plane); but both are linked to human life. Even though Jesus' statement referred to the Eucharist, his disciples found it difficult to understand how they could ingest the flesh and blood of Jesus. This unfortunately led some disciples to leave Jesus as they could not stand his talk on flesh and blood, and food and drink. The disciples could not imagine a situation in which they would drink blood and eat the flesh of men.

The Gospel of John connects the Eucharist to Jesus' testament in the farewell speech and we find the same in the testamentary tradition in Paul's account which places much emphasis on the need for communion and service of the Eucharistic table participants hence the 'paschal memorial principle of interpretation'. The four textual narratives in Mark 14:22-25; Matthew 26:26-29; Luke 22:15-20 and 1 Corinthians 11:23-26 would make much sense when interpreted from the paschal perspective in relation to the reign of God and Christ's kingship. The question is what is the place of blood amongst the Shona? Can it be related to the essence of blood in the Old and New Testament? 


\section{The Sanctity of Blood amongst the Shona}

The sacredness of blood and its association with life are also central to the Shona worldview and this understanding ensures that the concept of blood does not remain abstract to African students and Afro-Christians. It is no wonder that most African Christians are comfortable to make claims or prayers by evoking the blood of Jesus rather than the name of Jesus especially when they are praying for the sick and the demon possessed. It is easy for Afro-Christians to look for something which they are familiar with in order to bring the concept of the blood paradox nearer home. The sacredness of blood can be said to be the axiom and epicenter of the cosmology of Shona Afro-Christians. Blood links the individual to the clan as well as to the natural and the supernatural worlds. According to Magesa (1998:23), blood is the mystique force that connects the living and the living-dead. Baruch Levine quoted in Klawans (2001:14) explains that the spilling of blood and proper performance of sacrifice serve not only to attract the deity but also to maintain the deity's presence among the people concerned. In other words, a sacrifice carries a pleasant and pleasing odor to the deity and the ancestors. A similar point is noteworthy in the story of Abel and Cain (Genesis 3) or of Esau and Jacob (Genesis 28) in which YHWH found the sacrifice of Abel pleasing.

Kinship relationships which are basically patrilineal are broadly governed by blood and cemented by clan names (mitupo) as well as sub-clan names (zvidao). Relations between people of the same clan or sub-clan are further regulated through taboos. Such taboos influence how clan members relate to the animal that symbolizes their clan. Members of a particular clan are not allowed, inter alia, to kill or eat the flesh of their totemic animal, for example, a pig or an eland. This could also apply to other totemic birds and fish. Breaching such taboos is considered an abomination that attracts supernatural vengeance. Sexual relationships and marriage between people of the same clan are tabooed. Those who breach the incest taboo are viewed as outcasts and are often excommunicated. From a sociological perspective, Bourdillon (1990:11) reports that relationships between people who are related by blood or clan are forbidden because they upset the social order. Order in society is premised on a set of prescribed regulations. Magesa (1998:5) also affirms that incestuous acts are strictly forbidden because they disturb the wellbeing of the community and throw family and clan lineages into disarray. More importantly, he explains that incest is a glitch that blurs ancestral veneration and remembrance through naming.

Besides the above mentioned taboos, blood is highly respected especially the blood of a human being. Human life is inseparably bound to blood hence the shedding of human blood is considered a serious taboo. African communities such as the Shona and the Ndebele find it difficult to under- 
stand and accept the salvific role played by Jesus as a result of the painful death and sacrifice that he is purported to have undergone to save humanity. They find it easier to understand blood sacrifices of animals in the Old Testament than the New Testament version of Jesus' salvific role. Why did God not find a better way of saving humanity than choosing to sacrifice his son? Blood is not only conceived as a natural symbol of life but it is life itself. This is congruent with the Levitical idea that blood is life (Deuteronomy 12:23). A number of scholars agree that the sanctity of human life is in its blood (Mbiti 1969:18, 1975:4; Nabofa 1985:10; Magesa 1998:19).

Among the Shona Afro-Christians shedding blood results in the perpetrator being tormented by the spirit of the victim. Belief in avenging spirits (ngozi) is widespread and serves to demonstrate the sanctity of human blood (Bourdillon 1976:18; Shoko 2008:17). The issue of Jesus' blood cleansing human sin is better understood in the sense of Jesus paying an 'avenging spirit' or becoming an 'avenging spirit' to those who spilled his blood. It is not surprising to Afro-Christians that some people choose to remain celibate for Christ's sake, for example, Catholic nuns and priests. Some of them claim to be married to Jesus and declare, 'Murume wangu ndiJesu', that is, 'My husband is Jesus'. Such undertakings to become eunuchs (1 Corinthians 7) can only make sense when viewed from a Shona perspective in which people pay for $n g o z i$ by becoming 'wives' or 'husbands' to the avenging spirits. Even the shedding of the blood of certain animals, for example cats, is believed to attract post-mortem vengeance from the killed animal.

It is important to note that the intensity and extent of blood sanctity and mystic power differ according to its source of origin. Blood from certain parts of the body, for example, the reproductive organs is thought to be extremely sacred. Thus, blood resulting from deflowering a virgin girl is thought to be pure and laden with healing properties, as noted by Manyarara and Museka (2009:154) and by Manyonganise and Museka (2010:226). These scholars also report that the burgeoning cases of child sexual abuse have become rampant as bogus traditional healers prescribe ritual sex with minor virgins as a cure for HIV and AIDS or fertility ritual associated with the amassment of wealth. In these cases, the breaking of the hymen is thought to be transformative as it symbolizes the initiate's break away from the old self of either ill-health or vicious cycle of poverty into the new status of health and wealth. The oozing blood is thought to possess cleansing, energizing, revitalizing, and stabilizing mystical power. Mbiti (1969:11) observes that the blood of virginity is highly treasured in most parts of Africa. However, it is a taboo for a man to sleep with a female partner during her menstrual period as shall be shown later. The same understanding has been highlighted above under the Old Testament blood paradox.

PERICHORESIS 14.1 (2016) 
The sanctity of blood is further confirmed by sacrifices and offerings that are often given by descendants as gifts to the ancestors in reciprocating or in search of favors. In this dialectical relationship, animals for sacrifice are carefully selected to ensure that they are without blemish. The choice is usually determined by the animal type, color, sex, age, myths, and the overt characteristics which are thought to prefigure the animal's inner essence such as gentleness, calmness, and meekness. This practice correlates with Jewish sacrifices-gift offerings, burnt offerings and sacrificial meals (Genesis 4:3-4, 8:20, 12:6-8; Judges 16:23; 1 Samuel 6:4; 2 Kings 3:27; 5:17). In other words, the animals used in rituals are chosen on the assumption that the spiritual content of their blood is related to their natural characteristics. It is believed that the animal's qualities are transferred to the soul of the departed symbolically. It is therefore not surprising that pigs which are considered unclean in the biblical and traditional myths do not feature in Shona Afro-Christian rituals. In contrast, birds and animals such as doves, pigeons, chickens, goats, sheep, and cattle are commonly used. The main sacrificial animal is the sheep chosen by virtue of its gentleness even in the face of adversity.

The shedding of blood is a common feature in the Shona expiatory rituals. According to Nabofa (1985:396), 'such rites are based on the belief that there is a mystical power in blood which is capable of expiating guilt and impurities from man and his environment'. Furthermore, the Shona funerary and post-funerary rituals often require the slaughtering of some of the aforementioned pro-ritual animals particularly cattle. Nabofa also shows that the blood shedding requirement derives from the belief that blood is capable of setting off the guilt or defilement of the deceased and endowing him/her with energy to use upon returning to the earthly plane. The spiritual properties in the blood of a sacrificed animal are sometimes thought to purify not only the deceased but also those who would have been contaminated by coming in contact with the corpse. Given the centrality of blood in African rituals, we can argue that the doctrine of the crucifixion of Jesus which emphasizes the shedding and expiating function of blood was grudgingly accepted by many Shona traditionalists who find the human role of Jesus as a sacrifice problematic because most Africans do not use humans as sacrifices. The use of human blood in sacrifice is negatively associated with the practice of witchcraft, black magic, and sorcery. This is in spite of the fact that Jesus' blood, like the blood of animals used in rituals, is believed to establish a bond between divinity and the votaries through whom the deity manifests its power and presence.

Moreover, Jesus' blood covenant with Christian believers is reminiscent of the traditional blood covenants between two individuals or groups. Blood covenants as already shown involve the sharing of blood in order to concre- 
tize relationships. Magesa (1998:17) notes that the crucial aspect of this covenant is marked by the exchange of blood which is mixed with food or herbs, or by leaking the other party's blood as it oozes from the incisions. Chisahwira is a typical example of voluntary blood covenants or pacts among the Shona (Chikafu 2012:8). However, such covenants are no longer popular among the people because of the prevalence of Christianity. In addition, stories abound regarding women who use their menstrual blood to prepare love potions (mupfuhwira) for their loved ones or husbands. Although this culminates in an involuntary kind of covenant bond, Shoko (2012:48) asserts that mupfuhwira is meant to tame wayward and promiscuous husbands.

Similarly, the blood of sheep is often used in regressive rituals meant to reconcile estranged brothers. The wrangling parties would partake in a meal which denotes some kind of 'holy communion'. The 'communion' symbolically brings them together physically, spiritually and psychologically while the blood serves as a seal to the renewed bond (Nabofa 1985:396). The covenant symbolizes the giving of one's life to the other thereby bringing the two concerned parties closer to each other than to their kinship brothers. The two parties effectively become one. The scenario is noticeable among Shona Afro-Christians who have severed relationships with their kinsfolk in favor of 'brothers and sisters' bound to them through the blood of Jesus. The implication is that the blood covenant engenders an inviolable bond between the concerned parties. Until death, the two parties become inseparable. In the absence of covenant reversal rituals, the blood covenant is irrevocable. Failure to keep the terms and conditions of the covenant is believed to cause calamities of metaphysical proportion. This understanding of blood, as pure and sanctified, stands in sharp contrast to another view which portrays blood, even from the same source as impure, sacrilegious and defiling. This means that the attitude of the Shona Afro-Christians to and their understanding of blood are largely paradoxical. The ambiguity lies in the fact that blood is conceived not only as an embodiment of positive mysterious power, but also as harboring destructive forces.

\section{Danger Beliefs Associated with Blood amongst the Shona}

Given that the Shona Afro-Christians' cosmology is dominated by belief in the efficacy of spirits, witchcraft, sorcery, charms, and medicines, the use of blood to generate mystical power is not uncommon at all. Thus, Nabofa (1985:396) argues that when charms, (herbal) medicine or witchcraft arsenals are being prepared, the blood of a specially selected animal is added in order to provide the much needed spiritual potency. Human blood is said to be highly treasured by witches for its magical efficacy. In fact, witches are thought to be more interested in the blood of their prey than the flesh. Witchcraft beliefs are so widespread among the people that they interfere 
with Western-oriented HIV and AIDS mitigation measures. Museka (2012:10) observes that HIV and AIDS symptoms such as loss of weight, body weakness, paleness, and anemic appearance are invariably attributed to witchcraft by the Manyika-Shona ethnic group among which witches purportedly draw the blood of victims. To the Shona Afro-Christians, these symptoms are traced to the evil machinations of witches and sorcerers who enjoy eating the flesh and sucking the blood of their victims.

Furthermore, it is believed that practitioners of black magic and evil rituals desire human blood and flesh for their malevolent practices. In this regard, it is reasonable to suppose that the frequently reported cases of kidnapped children, missing people, and ritual murderers are related to the enormous demand for human blood to make new charms and more potent medicine, and to revive the supposedly weakening powers of the ritualists. In order to show how entrenched such beliefs are among the Shona AfroChristians, we shall highlight three of the suspected ritual murder cases reported in Zimbabwe newspapers. Prosper Dembedza reported the case of a two year old Marondera girl who went missing on April 18, 2014 only to be found with her right leg and private parts removed (Herald, 25 April 2014). Farai Kuvirimirwa wrote about a spate of suspected ritual killings that was taking place in the Mhondoro Mubaira area. In one of these suspected ritual murder cases, a girl was found with lowered pants, gorged eye, missing index finger and ear (Herald, 3 March 2014). Lastly, another Herald reporter related that a senior citizen was found killed with missing hair, left ear, eye, and scalp (Herald, 12 March 2012).

These cases illustrate the extent to which belief in the mysterious power and efficacy of human blood is deep-rooted in the belief system of the Shona Afro-Christians. Practitioners of 'black' magic, witches and sorcerers are believed to have an insatiable thirst for blood because of its ascribed power to nourish and make them more potent. Conversely, blood can be used as prophylactics against witches and sorcerers. This immunization is achieved by introducing a bitter concoction of herbs into one's bloodstream. The concoction is believed to make the person's blood bitter such that they acquire immunity against witches and sorcerers. Parrinder's (1951:169) observation among the Jukun of Northern Nigeria that 'anyone whose blood has a bitter taste is invulnerable to the attack of witches' equally applies to the Shona Afro-Christians. In other words, blood is considered a vehicle that carries and delivers preventive and curative medicine to all the parts of the body.

It is interesting to note that the magnitude of the mystic potency and dangers associated with blood varies with its source of origin. Thus, among the Shona Afro-Christians, blood resulting from menorrhagia and metrorrhagia is perceived to be dangerously polluting because it originates from 
the uterus. Levy-Bruhl (cited in Douglas 1988:46) describes blood from the two processes of menstruation and miscarriage as sacrilegious and tabooed. Husbands are not allowed to have sexual intercourse with their wives during menstruation, lest they lose their virility or become afflicted with an incurable venereal disease. Jewish prohibitions also touch on blood relating to menstruating women. The Shona Afro-Christians strongly believe that the blood that issues out of the female reproductive organ is impure and defiled hence any man who comes in contact with it becomes ritually unclean. Nabofa (1985:396) reasons that the belief that menstrual blood is unclean stems from the belief that it is a human being in a sense because if it had not flowed out it could have become a baby.

Menstrual blood therefore has the impossible status of a dead person that has never lived. Such blood is thought to render whoever touches it unwholesome ritually. Among the Shona Afro-Christians, it is a common practice that mature girls (who have attained puberty) and women of childbearing age are excluded from ritual activities. The reason is that their contiguity does not only contaminate other ritual participants and the ritual itself, but also offends the ancestor thereby making the ritual inefficacious. To avoid this sacrilege, virgin girls who have not started to menstruate and aged women who have attained menopause officiate in traditional rituals. Given the influence of the Bible (Judaism and Christianity) on Shona AfroChristians, it is not surprising that menstruating women voluntarily absent themselves from the Holy Communion in some Christian traditions. Even their practicing priests and votaries are widely rumored to forego their temple duties during menstruation. The reason for such abstinence is to avoid polluting the Communion and the temple in obedience to the Levitical law.

Similarly, in traditional religion or generally in African indigenous religions, it is believed that a menstruating woman ruins the medicine by preparing or touching it. As such, it is not uncommon for female traditional healers to take a leave during their menstrual period. In short, menstrual blood and discharges from the womb are considered unclean and taboo and these translate to ritual defilement. For Magesa (1997:139), danger beliefs associated with blood emanate from the fact that whilst most religious activities such as rituals and sex are life promoting, loss of blood conflicts with this notion. Thus, taboos against sexual intercourse during menstruation "play a significant role in the ethical duty of transmitting and preserving life, and the breach of taboos endangers the health and well-being of society' (Magesa 1997:139). Health and wellbeing are synonymous with the proper circulation of blood but when blood ceases to flow or oozes awkwardly, life is threatened.

PERICHORESIS $14.1(2016)$ 


\section{Unravelling the Blood Paradox}

Traditionally, the blood paradox in African indigenous religions was studied by evolutionary anthropologists. Evolutionists however were preoccupied with the idea of the origins of ritual sacrifices and not the meanings and structures ingrained in the paradox. Thus, according to this school of thought, ritual sacrifice originated as divine gift/food during the 'primitive' stage of religious development. The problem with this approach is that ritual sacrifices are dismissed as meaningless and vestigial religious practices from the dark ages. Thus, functionalists such as Girard (in Townsley 2003) consider ritual sacrifices as violence over a scapegoat or surrogate victim. This process is propelled by the desire to relieve frustration or societal conflict by lashing out at a defenseless innocent individual or animal. Through sacrifices, society avoids self-blame by heaping the blame on one victim.

Sacrifices serve an expiatory function in a somewhat irrational and cruel manner, a typical example being the crucifixion of Jesus. This understanding has been found wanting by ritual symbolists such as Douglas (1988:46, 1996:27) and Klawans (2001:18) who argue that rituals are not only meaningful but they are efficacious to the believer. According to Douglas (1996:27), refuse such as blood is given culture-specific symbolic meanings and whatever they symbolize should not be regarded as natural but as a social construction. Body symbolism therefore is always in service of social intentions. These social intentions are inextricably bound to the concept of body margins. All margins are thought to be dangerous and excretions that flow from these margins such as spittle, mucous, feces, urine, semen, and blood are considered impure and dangerous (Douglas 1988:48). By issuing the excretions, the persons involved are considered to have traversed the body margins and they possess lethal danger.

For Douglas (1988:47), rituals relating to blood are difficult to interpret unless the body is viewed as a symbol of society. This means the powers and dangers credited to the body margins/orifices should be viewed as the microcosm of the macrocosm. In the context of the Shona Afro-Christians, the notion of margins is evident in human interactions and in their engagement with the natural environment. Among the Shona, the mentally deranged, the disabled, and all who exhibit anomalous behaviors are thought to be in a marginal state. Even sacred places such as grooves, caves, rivers, and mountains form marginal zones. Such people or places are believed to exist outside the external boundaries of the social environment and are therefore set apart. Any unsanctioned interaction or interference with them is deemed to cause defilement.

Similarly, at a micro scale, body orifices symbolize vulnerable points and matter. In particular, blood from menstruation and miscarriage issuing from them is considered marginal stuff. Marginal substance is believed to be 
dangerous and defiling because it traverses the external boundaries of the body. Following this, a menstruating woman is viewed as being in a marginal or transitional state. According to Turner (1965:1), such a woman is neither here nor there; rather she is 'betwixt and between'. She is like an initiate who is supposed to die to her old life in order to be reborn. Given that such women are in a marginal condition, they have no place in the social system. Temporarily they are regarded as outcasts who are contagiously defiling, and all precaution against contamination by interacting with them must be exercised. This probably explains why women who are still undergoing their menstrual cycle are excluded from certain ritual procedures and it is anathema to have sex with them during menstruation.

Douglas (1988:47) further explains that blood ambiguity emanates from the traditional concept of hygiene. While there is no universally valid definition of dirt because dirt is a social construct, in this chapter, dirt is understood as matter out of place. This definition as noted by Mary Douglas, implies a contravention of a set of ordered relations. Dirt therefore is a byproduct of a systematic ordering, a rejection of elements out of place, and dichotomization of matter. Oozing blood is an anomaly and its recognition ignites anxiety. If uncontrolled, anxiety gives birth to disorder. In their quest to maintain order, the Shona like the Jews in the Old Testament formulated blood taboos as one way of dealing with unhygienic anomalous events. Thus, ideas relating to menstrual blood separation, purification, and affliction of transgressors serve to impose a system of order and hygiene. Although Douglas' observations are critical to the understanding of the blood paradox, they do not answer the question undergirding this study, that is, how can bodily refuse, in this case blood, be conceived as a symbol of purity, power, and danger?

This question can be answered with Jacob Milgrom's death avoidance theory (cited in Klawans 2001:27). In his analysis of the sources of ritual defilement, Milgrom observes that 'the common denominator here is death [...while] vaginal blood and semen represent the forces of life; their loss [symbolizes] death'. Thus, the system of defilement related to the body refuses to function to separate the forces of death which are impure from the forces of life which are holy. Given that in African indigenous cosmology blood resulting from menorrhagia and metrorrhagia is viewed as symbolizing a dead person (Nabofa 1985:396), taboos against getting in contact with such blood ought to be regarded as a symbolic system of death avoidance as in the Old Testament texts on menstruation which forbid contact with blood. Death is viewed as impure and the cadaver as defiling. This death avoidance theory explains why individuals are believed to be ritually defiled when genital fluid is lost through menstrual discharge. Sex or ritual exclu- 
sion during menstruation or womb discharges among the Shona AfroChristians should therefore be viewed as death avoidance.

Similarly, Eilberg-Schwartz (quoted in Klawans 2001:19) advances the idea of controllability and uncontrollability in trying to solve the blood purity-danger ambiguity. He contends that controllability seems to have influenced in no small measure the classification of substances which defile and the severity of the defilement. Eilberg Schwartz argues that the less body refuse can be controlled the more likely it is to defile. In contrast, controllable excrement is less contagious and defiling. Thus, the reason why miscarriage and menstrual blood are considered the most defiling of all body refuse is because they cannot be controlled. The same argument can be applied to blood which is shed during sacrifice in the sense that sacrifice is a controllable spilling of the blood (Levy Strauss, cited in Rappaport 1999:10), and it serves to correct a situation by symbolically reversing it. While his reasoning sounds convincing, it does not appear to be water-tight because there are various other body refuse which can hardly be controlled but are not considered as harmful as blood that exude from the genitals. Despite the inherent weaknesses, these theories are important to our understanding of the blood paradox which undergirds the Shona AfroChristian cosmology. While blood is generally considered symbolic, in ritual sacrifices it is seen as pure, meaningful, and efficacious. On the other hand, blood resulting from menorrhagia and metrorrhagia is thought to prefigure impurity and therefore is repulsive and repellent to the Supreme Being, ancestors and other vital forces which promote the health and wellbeing of the believers.

\section{The Place of the Blood of Jesus amongst Contemporary Christians}

The concept of blood conjures prophylactic memories in many Zimbabwean Christians. The blood of Jesus is regarded as capable of building new relations in the Christian community where totems for many Pentecostal Christians are not highly regarded or respected. What is respected is the blood line built on Jesus whereby even marriage is established on denominational lines. The blood of Jesus is regarded as reversing all forms of misfortunes that are linked to witchcraft, sorcery, diseases, unemployment, barrenness, and gender barriers. And on many occasions during prayer sessions, Zimbabwean Christians are fond of saying 'I am under the blood of Jesus'. It seems the blood of Jesus is more valued than the name of Jesus. Even though Scriptures talk about casting out demons or evil spirits in the powerful 'name of Jesus' Afro-Christians believe they find protection and assurance when they invoke the blood of Jesus. The blood of Jesus for them reminds them of the blood rituals that were accepted by the spirits in their prayer requests. It is not surprising that most vehicles and offices in Zimba- 
bwe carry stickers with statements such as 'I am covered by the blood of Jesus'. Public and private cars are awash with stickers that testify to the blood of Jesus more than the name of Jesus.

\section{Conclusion}

The blood paradox as shown in this chapter is universal and not limited to one given culture. It is clear that blood is linked to both life and death as life is regarded as resident in blood, and death therefore resembles the life moving out from the body. Animal sacrifices were performed as part of the prescription and presentation to the divine. The Old Testament presents death wherever the term blood is mentioned more than in the New Testament as shown in this study. The New Testament brings in the figure of Jesus as part of the salvific equation which only makes sense when taken from the perspective of the sacrificial victim.

\section{Bibliography}

Bernard JH (1969) A Critical and Exegetical Commentary on the Gospel according to St John. Volume 1. Edinburgh: T\&T Clark.

Biale D (2007) Blood and Belief: The Circulation of a Symbol between Jews and Christians. Los Angeles, CA: University of California.

Bokser BM (1987) Was the Last Supper a Passover Seder? Bible Review 3(2): 22-33.

Bourdillon MFC (1978) The Shona Peoples: An Ethnography of the Contemporary Shona, with Special Reference to their Religion. Gweru: Mambo Press.

Bourdillon MFC (1990) Religion and Society: A Text for Africa. Gweru: Mambo Press.

Brown RE (1966) The Anchor Bible: The Gospel according to John (i-xii). New York, NY: Doubleday and Company.

Campbell D, Johnston W (2000) Theological Wordbook. Nashville, TN: Word Publishing.

Chikafu PT (2012) Usahwira: A Look at the Old Testament Covenant Traditions from an African Perspective. Zomba: Kachere Series.

Douglas M (1966) Purity and Danger: An Analysis of the Concepts of Pollution and Taboo. London and New York, NY: Routledge and Kegan Paul.

Douglas M (1996) Natural Symbols: Explorations in Cosmology. London and New York, NY: Routledge.

Efird JM (1982) The Old Testament Writings: History, Literature, Interpretation. Atlanta, GA: John Knox Press.

Gilders WK (2004). Blood Ritual in the Hebrew Bible: Meaning and Power. Baltimore, MD: The Johns Hopkins University Press. 
Greidanus S (1999) Preaching Christ from the Old Testament: A Contemporary Hermeneutical Method. Grand Rapids, MI: Eerdmans.

Hagee J (2001) The Battle for Jerusalem. Nashville, TN: Thomas Nelson.

Harrington DJ (1991) The Gospel of Matthew. Collegeville, MN: The Liturgical Press.

Kent KW (2011) Deeper into the World: Old Testament: Reflections on 100 Words from the Old Testament. Bloomington, IN: Bethany House Publishers.

Klawans J (2001) Pure Violence: Sacrifice and Defilement in Ancient Israel. Harvard Theological Review (94)2: 133-155.

Ladd GE (1993) A Theology of the New Testament. Grand Rapids, MI: Eerdmans.

Machingura F (2012) The Messianic Feeding of the Masses: An Analysis of John 6 in the Context of Messianic Leadership in Post-colonial Zimbabwe. Bamberg: University of Bamberg Press.

Magesa L (1998) African Religion: The Moral Traditions of Abundant Life. Nairobi: Pauline Publications Africa.

Malina BJ, Rohrbaugh RL (1998) Social-Science Commentary on the Gospel of John. Minneapolis, MN: Fortress Press.

Manyarara BC, Museka G (2009) Ritual or Mere Sexual Aberration: A Comparative Analysis of Incest as Taboo in Zimbabwe and Caribbean Literary Works. UNISA Latin American Report 1(2): 154-167.

Manyonganise M, Museka G (2010) Incestuous Child Sexual Abuse in Shona Society: Implications on the Educational Achievements of the Girl Child. Zimbabwe Journal of Education Research 22(2): 226-241.

Marshall HI, Millard AR, Packer JI, Wiseman DJ (1997) New Bible Dictionary. Leicester: Intervarsity Press.

Martinez G (2003) Signs of Freedom: Theology of the Christian Sacraments. Mahwah, NJ: Paulist Press.

Mbiti JS (1969) African Religions and Philosophy. London: Heinemann.

Mbiti JS (1975) An Introduction to African Religion. London: Heinemann.

Museka G (2012) Medical Pluralism and the Quest for Therapy: The Dilemma of HIV and AIDS Patients in Zimbabwe's Rural Gandanzara Area. The Rose and Croix Journal 9: 1-17.

Nabofa MY (1985) Blood Symbolism in African Religion. Online: http://www.jstor.org/stable/20006199?Seq=1. Accessed on 14 April 2014.

Preuss DH (1996) Old Testament Theology. Volume 2. Louisville, KY: Westminster John Knox Press.

Rappaport RA (1999) Ritual and Religion in the Making of Humanity. Cambridge: Cambridge University Press.

Senior D (1989) Abingdon New Testament Commentaries: Matthew. Nashville, TN: Abingdon Press. 
Shoko T (2012) Karanga Men, Culture, and HIV in Zimbabwe. In Chitando E, Chirongoma S (eds) Redemptive Masculinities: Men, HIV and Religion. Geneva: WCC Publications, pp. 91-112.

Shoko T (2008) Spiritual Healing in Zimbabwe: Continuity and Change. Uppsala: Tryck.

Townsley J (2003) Rene Girard's Theory of Violence, Religion, and the Scapegoat. Online: www.jeramyt.org/papers/girard.html. Accessed on 8 February 2014.

Turner VW (1964) Between and Betwixt: The Liminal Period in the Rites de Passage. Online: www.fiu.edu/ ereserve/010010095-1.pdf. Accessed on 3 January 2014.

Wiersbe WW (1993) Wiersbe's Expository Outlines on the Old Testament: Strategic Chapters Outlines, Explained, and Practically Applied. Eastborne: Kingsway Communications.

Young R (1998) The Heart of the Old Testament. Grand Rapids, MI: Bakers Book House Company. 